\title{
Grafting of Styrene onto Commercial PTFE Membrane and Sulfonation for Possible Use in Fuel Cell
}

\author{
E.E. Abdel-Hady ${ }^{1}$, M.M. El-Toony ${ }^{2 *}$, M.O. Abdel-Hamed ${ }^{1}$ and A.M. Hammam ${ }^{3}$
}

${ }^{1}$ Physics Department, Faculty of Science, Menia University El-Menia City, Egypt

${ }^{2}$ National Center for Radiation Research and Technology, Atomic Energy Authority, Egypt

${ }^{3}$ Ahmad El-Zomr Street, P.O. Box 29- Nasr City, Cairo, Egypt

\begin{abstract}
Commercial poly tetrafluoroethylene (PTFE) inserted in silica with ratio of $8 \%$ was chosen. Gamma irradiation was used for grafting of different ratios of styrene onto membrane in one and / or two steps. Monomers mixture of styrene and each of methacrylic acid or acrylic acid were used as binary monomers for grafting of such membrane to raise the grafting percent and aids proton conductivity. Sulfonation of the grafted membrane was performed for hydrogen proton conduction enhancement. Confirmations of the grafting and sulfonation have been achieved by FTIR investigation while lon exchange capacity was studied as well. The mechanical properties of the grafted PTFE were tested by hardness tester while their thermal behaviors were investigated using thermal gravimetric analysis. It was found that maximum water uptake percent of the sulfonated membrane reached to $28 \%$ by weight. The proton conductivity of the prepared membranes were measured by AC impedance spectroscopic analysis, it was reached to $9.6 \times 10^{-3} \mathrm{Ohm}^{-1} \mathrm{Cm}^{-1}$ which is comparable to that of Nafion.
\end{abstract}

Keywords: PTFE membrane; Gamma irradiation; Silica; Monomers; Grafting; Sulfonation; AC impedance

\section{Introduction}

Current demands to improve PEMFC efficiencies and to reduce cost and complexity of the systems require operating temperatures above $100^{\circ} \mathrm{C}$. The membranes must be designed to maintain high proton conductivity at these temperatures, preferably approaching 100 $\mathrm{m} . \operatorname{simon} / \mathrm{cm}$, in combination with a high chemical and mechanical stability to endure fuel cell operation in excess of 5000 hours Current PEMFCs typically run at $\leq 80^{\circ} \mathrm{C}$ because of the working temperature limitation of the materials (usually Nafion). The high cost of the PEMFC is partially due to the expensive perfluorosulfonic membranes, such as Nafion membranes. Therefore, it is necessary to develop an alternative membrane which is less expensive and has a high performance. One of the ways is by modification of the commercial films using the radiation grafting method [1-12]. Recently, the radiation-grafted membranes have been well reviewed [1-3]. The grafting can be initiated by highenergy irradiation using Gamma-rays, electron-beam and swift heavy ions. Binary monomers of styrene/divinylbenzene (DVB) have been widely used as the graft components. Other monomers, such as styrene derivatives and acrylic monomers have also been investigated [5-10]. The base film in the membrane functions as a hydrophobic host that constrains the membrane swelling in water and provides mechanical strength and dimensional stability. The requirements for new membranes are somewhat related to those of PEMFC, but with an additional factor that since the fuel supplied to the anode is in liquid rather than gaseous form, swelling and crossover by methanol fuel must be controlled. The high permeability of methanol fuel from the anode to the cathode (crossover) through the currently used perfluorinated sulfonic acid membrane (Nafion) and the sluggish oxidation kinetics of methanol at the cathode pose serious problems for the commercialization of DMFC technology. Applications in terms of their lower weight and volume compared with indirect fuel cells. Furthermore, DMFC attracted interest for mobile and domestic application thanks to low operating temperature, fast start-up, and the easiness of fuel storage and transportation [13]. In order to improve the performance of the DMFC, it is necessary to eliminate or, at least, to reduce the loss of fuel across the cell membrane, usually termed "methanol crossover". DMFC systems are based on polymer electrolyte in the form of proton exchange membrane fuel cell (PEMFC). It offers simple and compact design as the methanol is fed directly into the fuel cell. In other words, a DMFC system does not require a bulky and heavy hydrogen storage system or a reforming subsystem. For the purpose of reducing methanol crossover in DMFC, many studies were reported; that includes sulfonated perfluorinated materials [14,15], sulfonated poly hydrocarbons [16-18], acid-base blends with a surplus of acid ionic groups [19-21], organic-inorganic composite materials $[22,23]$, and polymer blends [24]. There has been considerable effort spent trying to reduce methanol crossover and to reach high proton conductivity. Membranes containing metallic blocking layers have been proposed [25], and organic-inorganic composite membranes containing $\mathrm{Zr}$ phosphonates. [26], Sn-doped mordenites [27], zeolites [28], and silica [29] have been investigated. The preparation of hybrid organic-inorganic composites has attracted much attention because such hybrids may show controllable physical properties, such as optical, electrical, and mechanical behaviors, by combining the properties of both organic polymers and inorganic compounds [30,31]. In these organic-inorganic hybrids, the inorganic minerals precipitate in situ in a regular manner in the organic polymer matrix, and a strong interaction between the organic polymer and inorganic mineral is expected to result in a hybrid with markedly improved mechanical properties.

*Corresponding author: M.M. El-Toony, National Center for Radiation Research and Technology, Atomic Energy Authority, Egypt, E-mail: Toonyoptrade@yahoo. com

Received April 14, 2011; Accepted June 16, 2011; Published June 18, 2011

Citation: Abdel-Hady EE, El-Toony MM, Abdel-Hamed MO, Hammam AM (2011) Grafting of Styrene onto Commercial PTFE Membrane and Sulfonation for Possible Use in Fuel Cell. J Membra Sci Technol 1:108. doi:10.4172/2155-9589.1000108

Copyright: @ 2011 Abdel-Hady EE, et al. This is an open-access article distributed under the terms of the Creative Commons Attribution License, which permits unrestricted use, distribution, and reproduction in any medium, provided the original author and source are credited. 
In this work, grafting of commercial PTFE (hybrid membrane) by styrene and binary monomers with acrylic and / or methacrylic acid and sulfonation was further more carried out. Thermal, mechanical, and chemical characterizations of the grafted membrane were performed. Morphological studies of the grafted membranes were carried out using scan electron microscope. Ion exchange capacity and water uptake of the membranes was measured prior to AC impedance investigation for possible use of the prepared grafted membrane in fuel cell.

\section{Experimental Approach}

\section{Materials}

Commercial polytetrafuoroethylene film which inserted silica within its matrix, with thickness $120 \mu$ were used, purchased from OPTCo, Egypt.

- styrene of purity $99.9 \%$ and Methacrylic acid of purity $99.8 \%$ were supplied by Merck, Germany, other chemicals such as solvents, alkali acids....etc., were reagent grade (Data shown as supplementary).

\section{Polysulfone}

Preparation of grafted membrane: The direct grafting method was used as a technique in which the polymer and monomer solutions were subjected to ionizing radiation (Gamma rays ${ }^{60} \mathrm{Co}$ dose rate 1.22 Gy/Sec.) in a glass ampoule. After graft copolymerization, grafted films were washed with bi-distilled water and extracted with hot water to remove excess reagent. The films dried in vacuum oven at $30-40^{\circ} \mathrm{C}$ for 2 hours and weighed. The degree of grafting was determined by percent increase in weight using the following equation;

$$
\text { Degree of grafting } \%=\frac{\mathrm{W}_{\mathrm{g}}-\mathrm{W}_{\mathrm{o}}}{\mathrm{W}_{\mathrm{o}}} \times 100
$$

Where $\mathrm{W}_{\mathrm{o}}$ and $\mathrm{W}_{\mathrm{g}}$ represent the weight of initial and grafted film respectively.

Grafting with two steps were carried out by repeating grafting process by the same condition on the same membrane. Each step were performed via irradiation to $20 \mathrm{KGy}$, this technique was used to avoid reaching to the polymerization dose of styrene while increasing the free radials formation for PTFE film.

Sulfonation of grafted membrane: The sulfonation of phenyl group of styrene was carried out by soaking the grafted film in a mixture of chlorosulfonic acid and 1,2 dichloroethane with a ratio of 1:1 in ice bath for interval times (hours). The membranes were then washed with distilled water and dried in oven at $40^{\circ} \mathrm{C}$ [32].

Schematic representation of pore filling of porous PTFE films with PSSA using simultaneous Gamma irradiadtion-induced grafting of styrene and subsequent sulfonation. (1) Loading of styrene in the porous structure of PTFE film. (2) Grafting of styrene to form polystyrene pore-filled PTFE film using Gamma irradiation. (3) Solfonation of the polystyrene grafted in pores of PTFE films.

Water uptake studies: Respective water uptake / swelling behaviors of different ratios of grafted membranes were studied in water. Put a pieces $(2.5 \times 2.5 \mathrm{~cm})$ of membranes with known weight into glass ceiled ampoules filled with water for 24 hours. Swollen polymer was wiped off with tissue paper and then weighed immediately to know the swelling percent or water uptake percent, which was calculated as:

$$
\text { Water uptake } \%=\frac{- \text { Weight of swollengrafted membrane }}{\text { Weight of drygrafted membrane }} \times 100
$$

Ion Exchange Capacity (IEC): IEC of the sulfonated polymers was measured using a typical titration method. The dried membrane in the protonic form was immersed into $25.00 \mathrm{~mL}$ of $3 \mathrm{M} \mathrm{NaCl}$ solution for $24 \mathrm{~h}$. A large excess of $\mathrm{Na}^{+}$ions in the solution ensured nearly complete ion exchange. Then, $10.00 \mathrm{~mL}$ of the $3 \mathrm{M} \mathrm{NaCl}$ solution containing the released $\mathrm{H}^{+}$ions was titrated against $0.05 \mathrm{M} \mathrm{NaOH}$ solution using phenolphthalein as indicator. The IEC was calculated using the following equation:

$$
\text { Degree of grafting } \%=\frac{\mathrm{W}_{\mathrm{g}}-\mathrm{W}_{\mathrm{o}}}{\mathrm{W}_{\mathrm{o}}} \times 100
$$

Where $V \mathrm{NaOH}(\mathrm{mL})$ is the volume of the $0.05 \mathrm{M} \mathrm{NaOH}$ solution used for titration. $n$ is the factor corresponding to the ratio of the amount of $\mathrm{NaCl}$ solution taken to immerse the polymer $(25.00 \mathrm{~mL})$ to the amount used for titration $(10.00 \mathrm{~mL})$, which is $2.5 . W_{\text {dry }}(\mathrm{g})$ is the dry weight of the polymer electrolyte membrane in the protonic form.

AC impedance measurement: Proton conductivity measurements were of the sulfonated grafted membranes were derived from AC impedance spectroscopy measurements over a frequency range of 1 to $10^{7} \mathrm{~Hz}$ with an oscillating voltage of $50-500 \mathrm{mV}$, using a system based on a HIOKI LCR Hi-Tester, Model:3532, Japan. Each membrane sample was cut into sections $2.5 \mathrm{~cm} \times 2.5 \mathrm{~cm}$ prior to being mounted in the cell. The cell was placed in a temperature controlled container open to air by a pinhole where the sample was equilibrated at $100 \% \mathrm{RH}$ at ambient atmospheric pressure and clamped between two electrodes. The proton conductivities of the samples were measured in the longitudinal direction and were calculated from the impedance data, using the following relationship:

$$
\sigma=\frac{1}{\mathrm{RS}}
$$

where $\sigma$ is the proton conductivity (in $\operatorname{simon} / \mathrm{cm}$ ), 1 is the distance between the electrodes used to measure the potential $(\mathrm{l}=1 \mathrm{~cm}), S$ is the membrane cross-sectional surface area (membrane width $\times$ membrane thickness) for protons to transport through the membrane (in $\mathrm{cm}^{2}$ ) and $\mathrm{R}$ is derived from the low intersection of the high frequency semicircle on a complex impedance plane with the $\operatorname{Re}(\mathrm{Z})$ axis.

\section{Scientific equipments}

FTIR characterization: The functional groups of the grafted membrane were studied using Mattson 1000, Pye-Unicam, England.

\section{Thermalgravimetric analysis}

Shimadzu TGA -50, Japan, was used to characterize the thermal stability of the porous blend.

\section{Scan electron microscope}

Investigation and magnification of the polymer surface was carried out by SEM, JEOL-JSM-5400; Japan.

Calibration data:-Gain factor: 49.996 live time: 80 seconds.

\section{Sample data}

-Total spectrum count: 875722 , live time 70 seconds -System resolution: $173 \mathrm{ev}$

-Accelerating voltage: $20,00 \mathrm{Kv}$.

\section{Hardness tester}

Samples of were cut for $2.5 \times 2.5 \mathrm{~cm}$ for hardness test. The measurement was carried out according to (ASTM D2240, 2000) by 
Citation: Abdel-Hady EE, El-Toony MM, Abdel-Hamed MO, Hammam AM (2011) Grafting of Styrene onto Commercial PTFE Membrane and Sulfonation for Possible Use in Fuel Cell. J Membra Sci Technol 1:108. doi:10.4172/2155-9589.1000108

manual analogue instrument with pin produced termed Baxio, UK.The unit of hardness is expressed in (Shore A).

\section{Gamma irradiation}

Gamma irradiation was carried out by ${ }^{60} \mathrm{Co}$ gamma rays with a cylinder irradiation chamber. All irradiations were performed at ambient temperature (about $45^{\circ} \mathrm{C}$ at the chamber) and a dose rate of about $1.22 \mathrm{~Gy} / \mathrm{Sec}$.

\section{Results and Discussion}

\section{Theoretical approach}

Organic-inorganic composites represent a useful approach. interesting reviews $[33,34]$ or presentations on the preparation of original high temperature-DMFC membranes arising from composites made of fluoropolymers doped with fillers or solid inorganic proton conductors (zirconium hydrogen phosphates, hygroscopic oxides, heteropolyacids, (HPA), phosphotungstic acid (PWA), etc.). These membranes were tested at temperatures up to $120^{\circ} \mathrm{C}$ under ambient pressure and up to $150^{\circ} \mathrm{C}$ under pressure of 3-4 atm.

Preparing organic/inorganic hybrid polymers is an interesting way to improve the thermal stability of membranes. Three alternatives are possible to incorporate silica into organic matrices.

(i)formation of two interpenetrating network (organic and inorganic); (ii)elaboration of a silica gel by acidic catalysis around a polymeric film;

(iii)'copolymerization' of an organic monomer with a siliated derivative.

The use of polysiloxanes gives copolymers with lower Tg, increased thermal stability of the hybrid system and decreased methanol crossover. Silica particles increase the water retention and hence the protonic conduction at high temperature.

Jung et al. [35] have reported the synthesis of a Nafion w 115 / Silica composite membrane obtained via the sol-gel acidocatalyzed of tetraethoxysilane (TEOS) (equivalent weight 1100). The amount of TEOS impregnated in the membrane varied with the reaction time. It was noted that; the water absorption of the composite membrane increased with the silica content, while the proton conductivity decreased. The silica particles inhibited the proton transfer. The methanol permeability of that membrane was that of Nafion, and

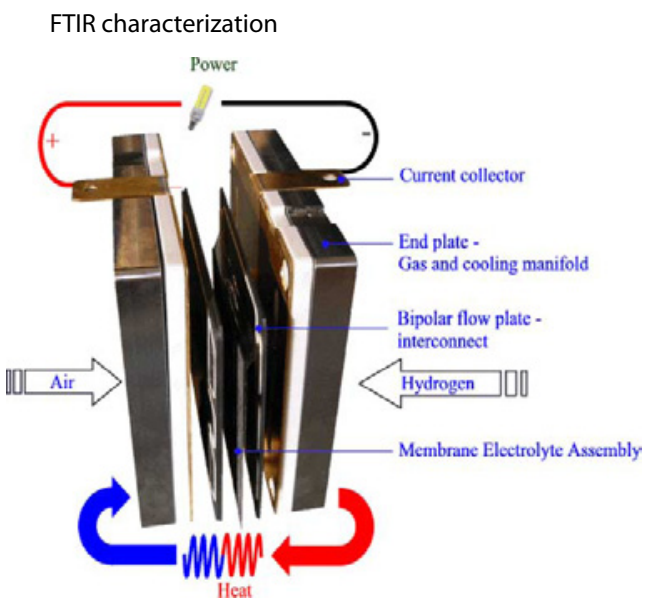

Figure 1: Schematic representation of a fuel cell [3].

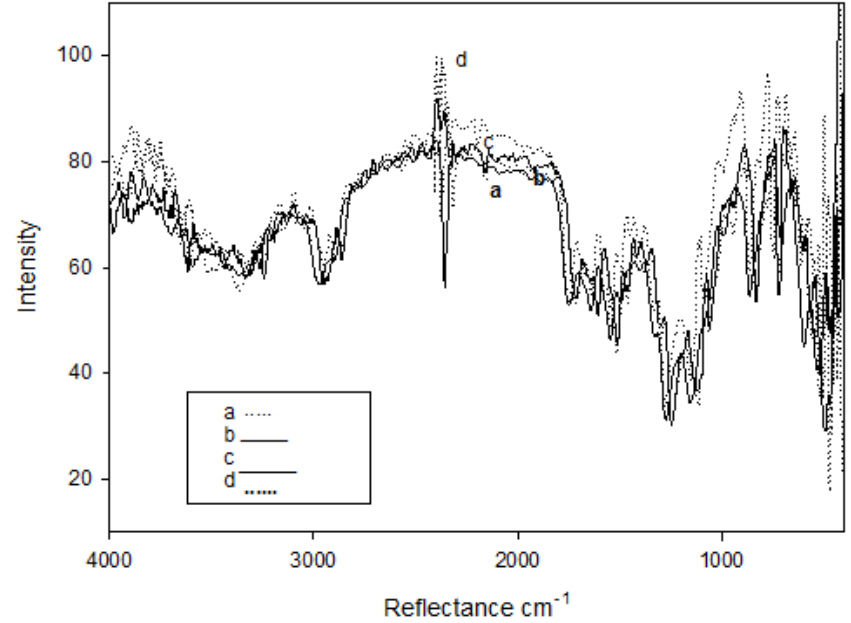

Figure 2 : Chart of FTIR of sulfonated (different sulfonation time) grafted styrene onto PTFE membrane, a ) $1 \mathrm{~h}$. sulfonation b) $2 \mathrm{~h}$. sulfonation c) $3 \mathrm{~h}$. sulfonation d) $4 \mathrm{~h}$. sulfonation.

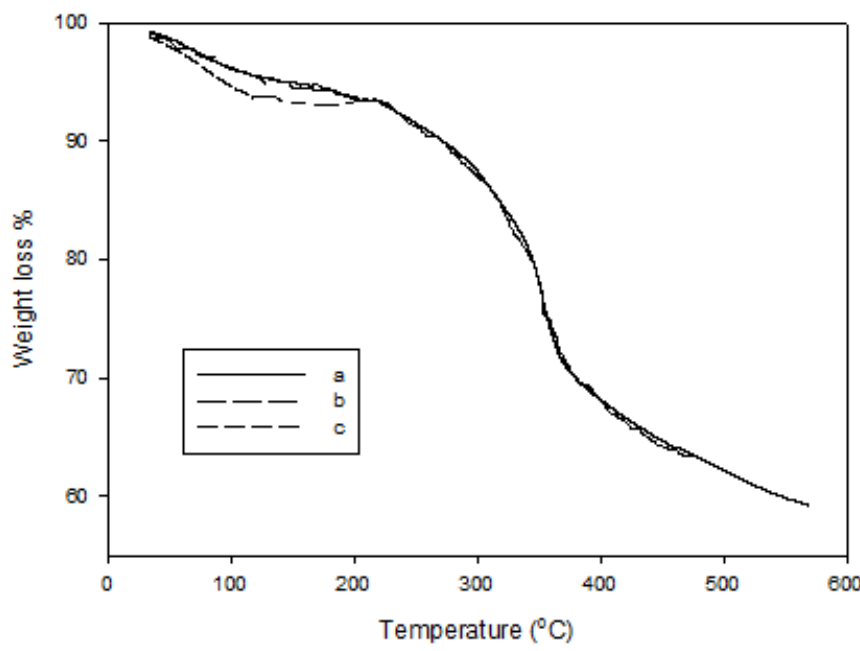

Figure 3: Thermogram of sulfonated (complete) styrene grafting PTFE with different grafting yield $(15 \%, 22 \%$ and $31 \%)$.

the performance of the membrane in fuel cell improved up to a silica content of $12.4 \%$, leading to potential applications in DMFC; for $0.5 \mathrm{~V}$, the current density at $125^{\circ} \mathrm{C}$ was $650 \mathrm{~mA} \mathrm{~cm}{ }^{2}$.

\section{Characterizations of the grafted membrane}

FTIR spectral analysis has been used to verify the incorporation of a PSSA moiety into the porous structure of the PTFE membrane and the formation of a polymer electrolyte membrane, as seen in Figure 2. comparison between a PSSA and its corresponding PS pore-filled PFE and a pristine PTFE membrane clearly shows that the PTFE membrane is grafted with PS, as revealed by benzene ring features and mono-substitution identified by a band at $749 \mathrm{~cm}^{-1}$. This band almost vanishes on sulfonation (confirmed by sharp bands of $\mathrm{SO}_{3}{ }^{-}$at 1007 and $1126 \mathrm{~cm}^{-1}$ ) with the appearance of a di-substituted benzene ring peak at $1034 \mathrm{~cm}^{-1}$. This confirms a degree of sulfonation close to $100 \%$. Broad band may appear extend from 1007 to 1034 as seen in Figure 2d which also confirm the complete sulfonation, while intensity of peak 
Citation: Abdel-Hady EE, El-Toony MM, Abdel-Hamed MO, Hammam AM (2011) Grafting of Styrene onto Commercial PTFE Membrane and Sulfonation for Possible Use in Fuel Cell. J Membra Sci Technol 1:108. doi:10.4172/2155-9589.1000108

assure hydrophilicity of membrane which originate as long contact time between membrane and chlorosulfonic acid.

\section{Thermogravimetric analysis}

The thermogram could be divided into 5 divisions depending on similar behaviors of the attained results of the different grafting membranes' response by raising the temperature. First division showed a decrease in weight at low temperature with a nearly constant shape. This division has a wide range of temperature at $15 \%$ grafting percent, it decreased to $120^{\circ} \mathrm{C}$ with $22 \%$ grafting percent while it reduced to $100^{\circ} \mathrm{C}$ when grafting percent reached to $31 \%$. Second division described a thermal stability through loss of weight did not exceed $5 \%$ for all understudied membranes. This division ranged $\left(120-200^{\circ} \mathrm{C}\right)$ at $15 \%$ grafting percent , it widen for $22 \%$ grafting percent membrane to $150-200^{\circ} \mathrm{C}$ while it reduced for $31 \%$ grafting percent to a range of 100 -

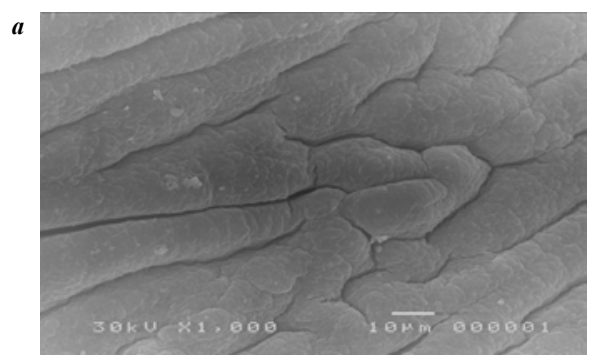

b

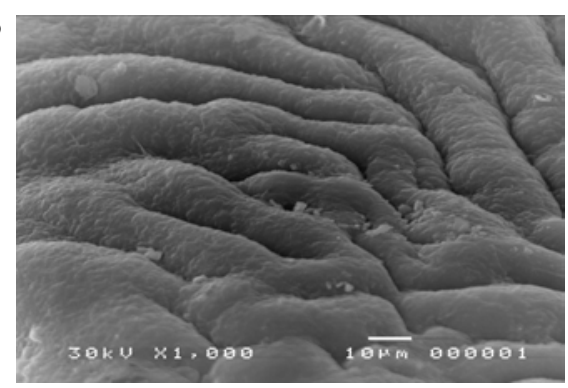

c
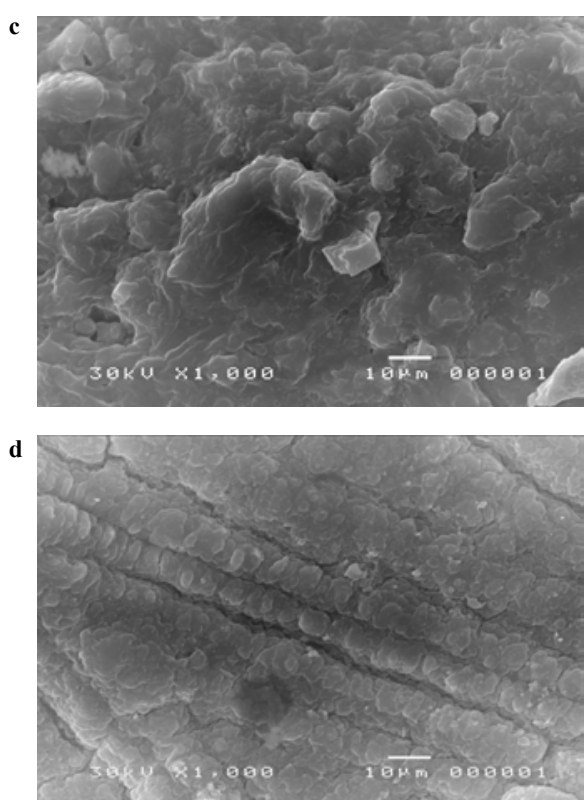

Figure 4: Scan electron microscope of styrene grafted into PTFE membrane $(31 \%)$ and sulfonation for a) 1 hour, b) 2 hours, c) 4 hours d) 6 hours.

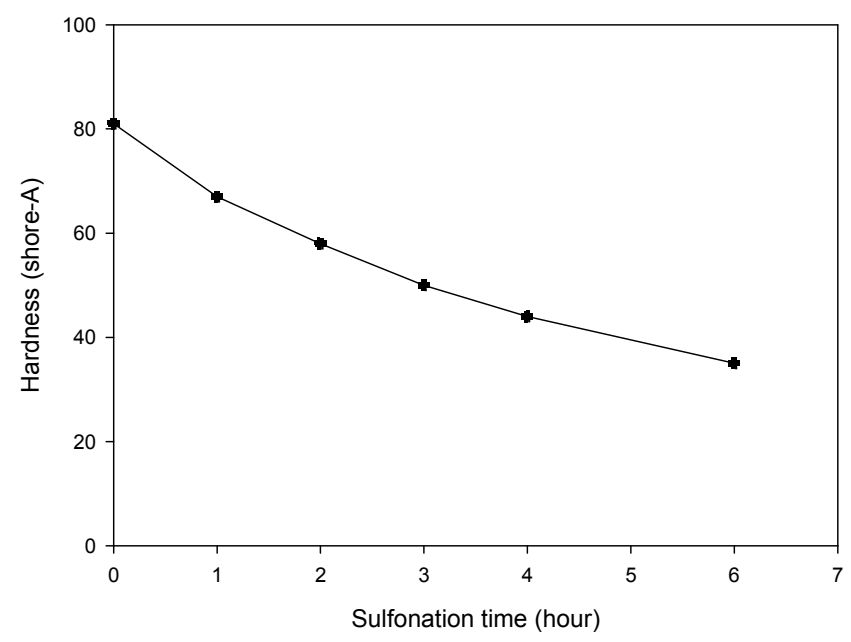

Figure 5: Effect of sulfonation time of PTFE grafted with styrene $(34 \%)$ on hardness of the membrane.

\section{Grafting Percent}

Grafting with styrene and binary monomers

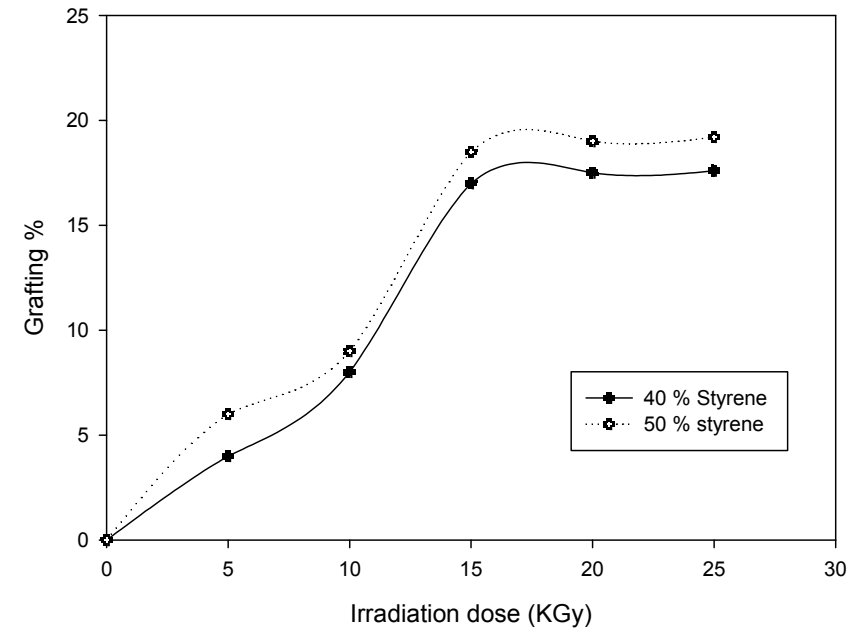

Figure 6: Effect of Gamma irradiation dose (KGy) on grafting percent of styrene onto PTFE membrane.

$150^{\circ} \mathrm{C}$. The third division described the convex thermogram regarding to temperature axe. These properties showed nearly same length of temperature $\left(130-140^{\circ} \mathrm{C}\right)$, it started from $200-330^{\circ} \mathrm{C}$ for 15 and $22 \%$ grafted membranes while the range start from $150^{\circ} \mathrm{C}$ to $290^{\circ} \mathrm{C}$ for $31 \%$ grafted membrane. The fourth division described the abrupt change of weight loss which showed an obvious different changes. The range of this division has a constant range $\left(200-330^{\circ} \mathrm{C}\right)$ corresponding to 15 and 22 grafting percent of the membranes. While this range widen include a range of $290-400^{\circ} \mathrm{C}$. Through this division loss of weight for the thermograms are nearly constant (30\% loss of weigh for $15 \%$ grafted membrane, $33 \%$ loss of weight for $22 \%$ grafted membrane and $35 \%$ loss of weight for $31 \%$ grafted membrane). These results attempt on a less thermal stability upon raising grafting percent. The fifth division showed a low rate of weight loss in a range of 400 to $580^{\circ} \mathrm{C}$. Loss of weight was nearly constant which was about $40 \%$ (41\% loss of weight for 15 grafted membrane, $41 \%$ loss of weight for $22 \%$ and $31 \%$ grafted membrane). 
Citation: Abdel-Hady EE, El-Toony MM, Abdel-Hamed MO, Hammam AM (2011) Grafting of Styrene onto Commercial PTFE Membrane and Sulfonation for Possible Use in Fuel Cell. J Membra Sci Technol 1:108. doi:10.4172/2155-9589.1000108

\section{Scan electron microscope}

Grafting percent and furthermore sulfonation affect severely on the PTFE membrane morphology. Surface area increased with sulfonation time from 1 to 6 hours, grooves and channels are seen while it widens as it seen in Figure 4a and Figure 4b. further sulfonation conduct opening these channels in different positions leading to facilitation of ion transfers through the pores originates as complete sulfonation. Distribution of pores through the membranes surface area homogenously as seen in Figure (4c). Degradation of the membrane is noticed in maximum form in Figure $d$ while maximum surface area is seen as well which confirmed the less mechanical properties as shown in figure (4d).

\section{Hardness investigation}

The membrane used in fuel cell acts as a carrier for proton transport and as a barrier to provide effective separation between the anode and cathode. The former requires the membrane to be as thin as possible, while the latter requires the membrane to be strong enough to avoid damage during the membrane electrode assembly (MEA) fabrication, and during the fuel cell operation. Especially in a DMFC, one side of the membrane is exposed to the liquid methanol solution, and the other side is exposed to the dry gas. Different swelling on the two sides will accelerate the degradation of the fuel cell membrane. In many cases, it is found that the degradation of the fuel cell is not only caused by the lower chemical stability, but by mechanical damage.

Evaluation of the mechanical properties of highest value of grafting ( $34 \%)$ of the styrene grafted membranes have been evaluated. Hardness measurements showed decrease their value by increasing the contact time of sulfonation. Regular decrease of hardness was noticed in Figure 5 by sulfonation's contact time. As it is seen 6 hours is severely affected the hardness of the membranes which reached to half its value at zero contact time. So 3 hours contact time is recommended to be used while it performed nearly complete sulfonation.

Irradiation dose on the grafting yield was studied in the range of $5-25 \mathrm{kGy}$ at constant $5 \mathrm{kGy}$ per pass. As shown in Figure 6, the grafting yield increases gradually with the increase irradiation dose. This can be explained by the fact that; with the increasing the irradiation dose, the production rate of radicals' formation within the grafting system

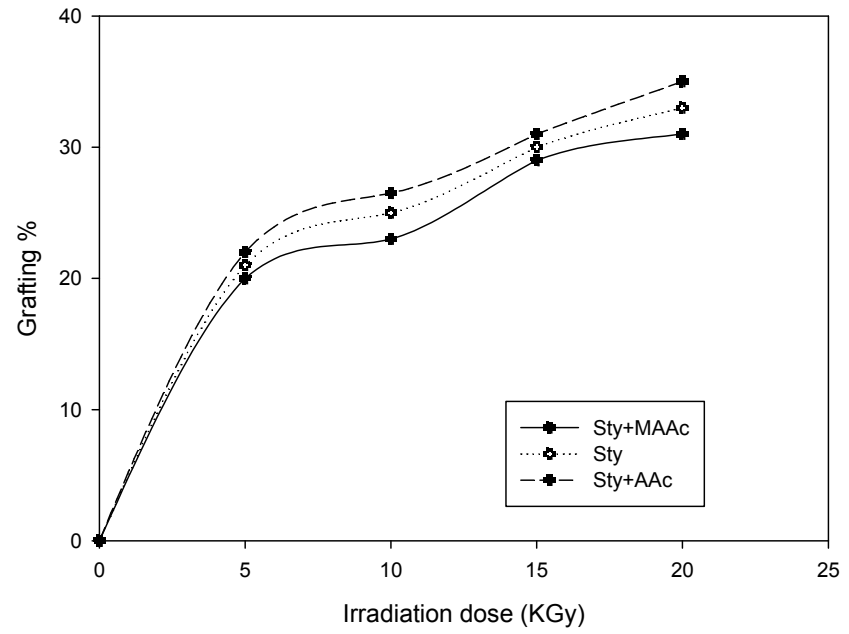

Figure 7: Effect of Gamma irradiation dose (KGy) on grafting percent of binary monomers onto PTFE membrane.

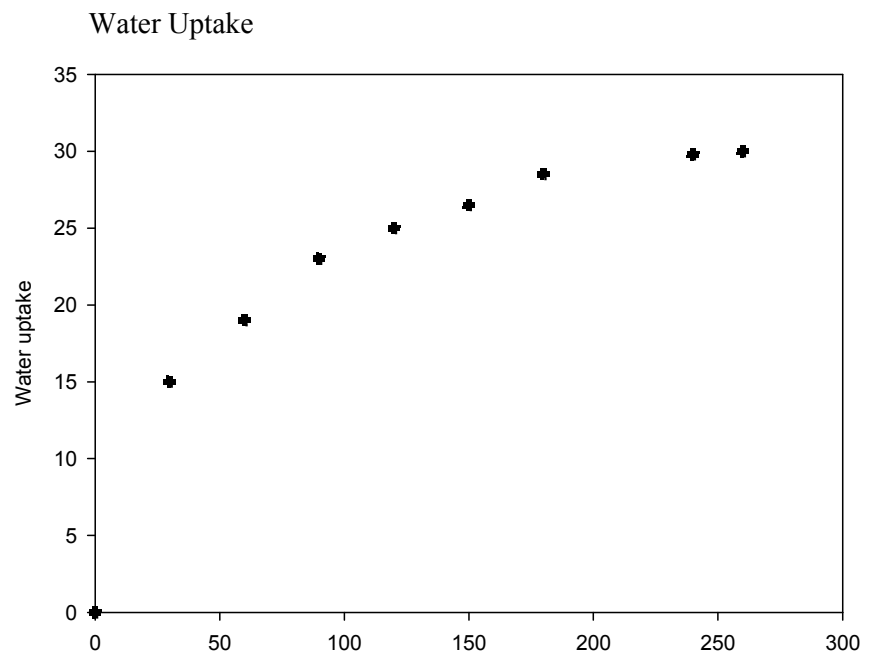

Figure 8: Effect of sulfonation time on water uptake of styrene Grafting PTFE membrane.

Ion Exchange Capacity (IEC)

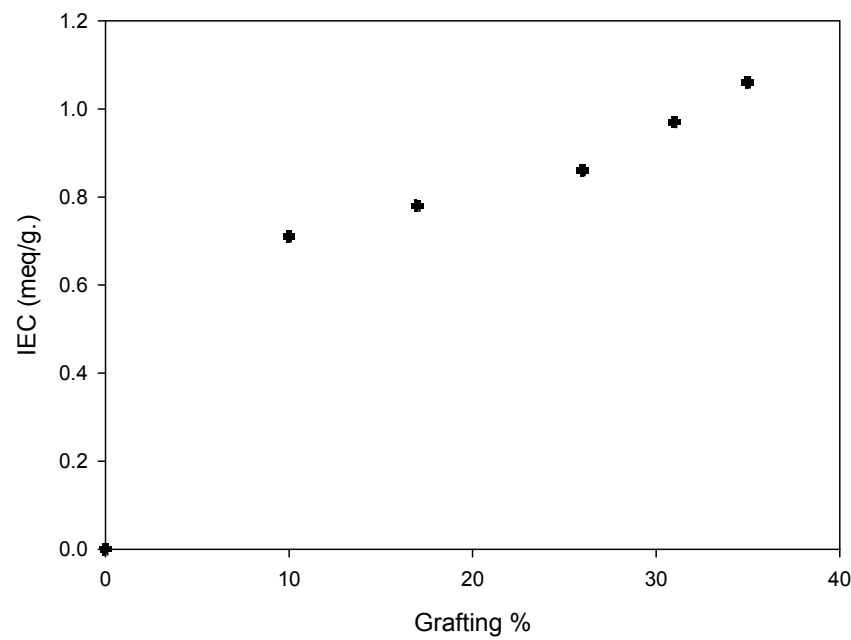

Figure 9: Effect of grafting \% on ion exchange capacity of styrene grafted PTFE and sulfonation for $4 \mathrm{~h}$.

was increased. Therefore, more radicals are available to take part in the monomer impregnation copolymerization reaction that consequently increases the grafting yield of the resulting membrane to a certain value after which it became constant. These results coincide with the result of previous researchers, who found that the grafting yield could be controlled by varying the irradiation dose [36-38] as a function of monomer concentration ranging from 20 to 100 vol.\%. This volume percentage corresponds to the amount of monomer absorbed into the pores and retained on the surfaces of the pristine film.

As shown, the extend of grafting yield only moderately increases with monomer concentration over most of the range studied, but relatively an abrupt increase in grafting yield values are observed in the bulk monomer concentration, which suggests better monomer diffusivity into the film pores in the absence of solvent. The amount of grafting yield anchored in the pore filled films are governed by the monomer diffusivity through the film, its concentration in the grafting 
layers and also the effect of irradiation dose that correlates to the amount of radical formed within the polymer matrix. The acceleration of the grafting yield in $100 \mathrm{vol} . \%$ monomer concentration is assumed to be due to the increase in the availability of the monomer to the radical sites and also the capability of the polymer backbone radical to capture the styrene radical that depends on the monomer concentration presence in its vicinity. Furthermore, higher irradiation dose results in the enhancement of the anchored polystyrene grafts into the interior of PTFE film so it can repeat the grafting by the same condition on the same membrane after washing and drying to avoid polymerization of styrene (homopolymer formation). While further irradiation on PTFE membrane conduct more free radicals formation which raise up the degree of grafting. Binary monomers used raise up grafting percent as monomer add enhance grafting of the main monomer (styrene). Acid add (acrylic acid, methacrylic acid) stimulates graft yield increase comparing to single monomer grafting [39] as seen in Figure 7. Acrylic acid raise grafting onto PTFE more than methacrylic acid which is may due to low molecular weight leading to good chance to reach membrane's reaction zone. This finding is relatively in agreement with the results of Zhi-Li et al. [40], who studied the radiation graft

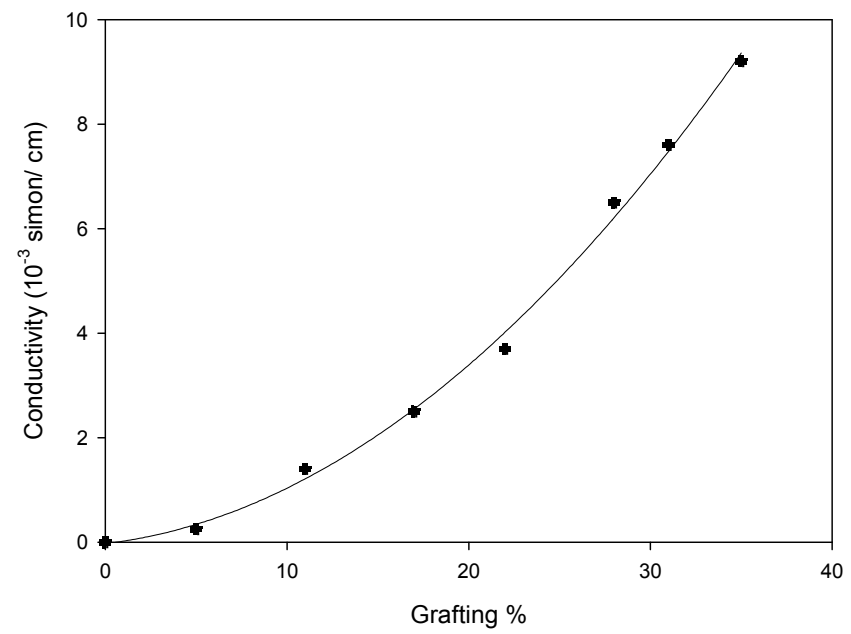

Figure 10: Effect of frequency on dielectric of sulphonated grafted membrane after 4 hours sulphonation.

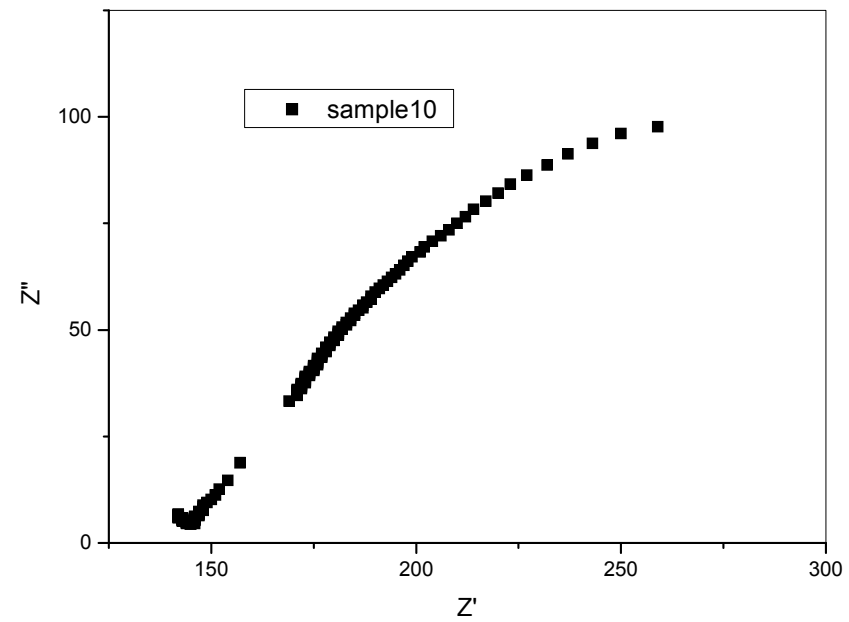

Figure 11: Effect of grafting \% of styrene onto PTFE grafted and sulfonted membrane on Ac conductivity. copolymerization of vinylimidazole (VI) onto PTFE films, respectively.

An increase in the water uptake of membranes with the increase in the degree of grafting and furthermore sulfonation was observed in Figure 8 . The non cross-linked membranes have been also studied [41]. The increase in swelling corresponds well with the higher content of sulfonic acid groups with the increase degree of grafting, which in turn increase the membranes hydrophilicity. The water uptake increased with sulphonation till 90 minutes (contact time) at which water uptake value were $22 \%$. Rising up the contact time leads to gradual increase of water uptake till reach to $28 \%$ after 260 minutes.

The ion exchange capacities were determined by acid-base titration and are plotted in Figure 9. It was found that the ion exchange capacity increases with an increase in the degree of grafting, and is independent of the nature of the base films Below a $25 \%$ degree of grafting, it was found that each aromatic group of the graft chains is attached to one sulfonic acid group, and thus the obtained degree of sulfonation is close to $100 \%$. However the value of IEC is over $25 \%$, clearly deviated of the theoretical value. Even then, the degree of sulfonation is greater than $85 \%$. Therefore, the ion exchange capacity could be freely controlled by changing the degree of grafting

\section{AC Impedance}

Figure 10 showed the Cole- Cole plot (Nquist plot) of styrene grafted PTFE at $300 \mathrm{~K}$. The plot shows a high- frequency semi-circle and a low frequency spike for DG. It was reported [42] that, the high- frequency semi-circle is due to the parallel combination of bulk resistance, because of protons migration, and bulk capacitance, due to immobile polymer chains. The bulk resistance can be calculated from the intercept of low-frequency spike or of high frequency PSSA grafted membranes versus the grafting yield are presented in Figure 11 together with that for a Nafion 117 membrane. The ionic conductivity increases with increase in grafting \%. Membranes with values of $19 \%$ grafting and above record an ionic conductivity as high as $10^{-3}$ simon $\mathrm{cm}^{-1}$. The threshold ionic conductivity value is given by the membrane with grafting of $35 \%$, viz., $9.6 \times 10^{-3}$ simon $\mathrm{cm}^{-1}$. This ionic conductivity is comparable to that of a Nafion 117 membrane, which was found to be $5.3 \times 10^{-2}$ simon $\mathrm{cm}^{-1}$ under the same experimental conditions. The dependence of the ionic conductivity of PSSA membranes on the grafting yield $(Y \%)$ presented in Figure 8 is probably caused by the increase in both sulfonic acid groups associated with the amount of the sorbed water. This indicates that the incorporation of more PSSA provides a better environment for ionic mobility in these polymer membranes. Since there is a relation between the water sorption and the ionic conductivity based on the concept of ionic domain percolation, the high-ionic conductivity demonstrated by these membranes at highgrafting yields, i.e., $Y=30$ and $35 \%$, suggests that the water swollen ionic domains in the membranes form a network structure. Therefore, the lower ionic conductivity observed for membranes with low grafting yields such as 8 and $19 \%$ is due to a diffusion limitation caused by segregation in the ionic domains. As the grafting yield increases to a sufficient level (34\%), the ionic domains become more interconnected and reach a percolation threshold beyond which diffusion limitations are overcome and allow the ionic conductivity to reach a maximum value.

\section{Conclusion}

This work has been performed for the purpose of synthesis of new membranes have low cost and availability for using in a fuel cell application. A hybrid commercial fluorinated membranes (poly 
Citation: Abdel-Hady EE, El-Toony MM, Abdel-Hamed MO, Hammam AM (2011) Grafting of Styrene onto Commercial PTFE Membrane and Sulfonation for Possible Use in Fuel Cell. J Membra Sci Technol 1:108. doi:10.4172/2155-9589.1000108

Page 7 of 8

tetrafluoroethylene is inserted through silica with $8 \%$ by weight) were used. Simultaneous gamma irradiation proved to be effective tool for grafting styrene into the PTFE membranes. FTIR confirmed the grafting with different yields and sulfonation has been done as well. Ion exchange capacity was evaluated while the membrane hardness approved their durability. Characterization of the membrane including morphological properties, thermal behavior and water uptake have been carried out. Electrical investigation of the grafted membrane confirmed their usage in fuel cell as their value (nearly $1 \times 10^{-2}$ simon/ $\mathrm{cm})$ is comparable to that of Nafion $\left(5.3 \times 10^{-2}\right)$.

\section{Aknowledgement}

The authors would like to express the deepest gratitude and thanks to prof Dr. Abdel-Razek Hussien professor of nuclear physics in Atomic Energy Authority for continuous interest.

\section{References}

1. Dargaville TM, George GA, Hill DJ, Whittaker AK (2003) High energy radiation grafting of fluoropolymers. Prog Polym Sci 28: 1355-1376.

2. Nasef MM, Hegazy EA (2004) Preparation and applications of ion exchange membranes by radiation-induced graft copolymerization of polar monomers onto non-polar films. Prog Polym Sci 29: 499-561.

3. Souzy R, Ameduri B (2005) Functional fluoropolymers for fuel cell membranes. Prog Polym Sci 30: 644-687.

4. Gubler L, Gursel SA, Scherer GG (2005) Radiation grafted membranes for polymer electrolyte fuel cells. 5: 317-335.

5. Assink RA, Arnold Jr C, Hollandsworth RP (1991) Preparation of oxidatively stable cation-exchange membranes by the elimination of tertiary hydrogens. J Membr Sci 56: 143-151.

6. Chen J, Asano M, Yamaki T, Yoshida M (2005) Preparation of sulfonated crosslinked PTFE-graft-poly(alkyl vinyl ether) membranes for polymer electrolyte membrane fuel cells by radiation processing. J Membr Sci 256 : 38-45.

7. Chen J, Asano M, Yamaki T, Yoshida M (2006) Preparation and characterization of chemically stable polymer electrolyte membranes by radiation-induced copolymerization of four monomers into ETFE films. J Membr Sci 269: 194204.

8. Horsfall JA, Lovell KV (2002) Comparison of fuel cell performance of selected fluoropolymer and hydrocarbon based grafted copolymers incorporating acrylic acid and styrene sulfonic acid. Polym Adv Technol 13: 381-390.

9. Momose T, Yoshioka H, Ishigaki I, Okamoto J (1989) Radiation grafting of a,b,btrifluorostyrene onto poly(ethylene-tetrafluoroethylene) film by preirradiation method. I. Effects of preirradiation dose, monomer concentration, reaction temperature and film thickness. J Appl Polym Sci 37: 2817-2826.

10. Rager T (2003) Pre-irradiation grafting of styrene / divinylbenzene onto poly(tetrafluoroethylene-co-hexafluoropropylene) from non-solvents. Helv Chim Acta 86: 1966-1980.

11. Scott K, Taama WM, Argyropoulos P (2000) Performance of the direct methanol fuel cell with radiation-grafted polymer membranes. J Membr Sci 171: $119-130$.

12. Oshima A, Ikeda S, Katoh E, Tabata Y (2001) Chemical structure and physical properties of radiation-induced crosslinking of polytetrafluoroethylene. Radiat Phys Chem 62: 39-45.

13. Kordesch K, Simader G (1996) Fuel Cells and Their Applications. VCH.

14. Yang B, Manthiram A (2004) Multilayered membranes with suppressed fue crossover for direct methanol fuel cells. Electrochem Commun 6: 231-236.

15. Hobson LJ, Ozu H, Yamaguchi M, Hayase S (2001) Modified Nafion117 as an improved polymer electrolyte membrane for direct methanol fuel cells. $J$ Electrochem Soc 148: A1185-A1190.

16. Glipa X, Haddad ME Jones DJ, Rozi'ere J (1997) Synthesis and characterization of sulfonated polybenzimidazole: a highly conducting proton exchange polymer. Solid State lonics 97: 323-331.

17. Kobayashi T, Rikukawa M, Sanui K, Ogata N (1998) Proton-conducting polymers derived from poly(ether-etherketone) and poly(4 phenoxybenzoyl1,4-phenylene). Solid State lonics 106: 219-225.

18. Baradie B, Poinsingon C, Sanchez JY, Piffard Y, Vitter G, et al. (1998) Thermostable ionomeric filled membrane for $\mathrm{H}_{2} / \mathrm{O}_{2}$ fuel cell. J Power Sources 74: 8-16.

19. JA Kerres (2001) Development of ionomer membranes for fuel cells. J Membr Sci 185: 3-27.

20. Kerres JA, Ullrich A, Meier F, Haring T (1999) Synthesis and characterization of novel acid-base polymer blends for application in membrane fuel cells. Solid State Ionics. 125: 243-249.

21. Jeon $\mathrm{CH}$, Venkataramani S, Kim SC (2006) Modification of Nafion membrane using poly(4-vinyl pyridine) for direct methanol fuel cell. Polym Int 55: 491-499.

22. Zaidi SMJ, Mikhailenko SD, Robertson GP, Guiver MD, Kaliaguine S (2000) Proton conducting composite membranes from polyether ether ketone and heteropolyacids for fuel cell applications. J Membr Sci 173: 17-34.

23. Aric'o AS, Creti P, Antonucci PL, Antonucci V (1998) Comparison of ethanol and methanol oxidation in a liquid-feed solid polymer electrolyte fuel cell at high temperature. Electrochem Solid-State Lett 1: 66-68.

24. Choi J, Kim IT, Hong YT, Kim SC (2005) Nafion-sulfonated poly (arylene ether sulfone) composite membrane for direct methanol fuel cell. Macromol Res 13 514-520.

25. Dohle H (1999) German Patent. 131C1,1980.

26. Hamlen RP (1998) Membrane for Hydrogen and Methanol Fuel Cell. US Patent $5,849,428$.

27. Kjar J, Yde-Andersen S, Knudsen NA, Skou E (1991) Solid state electrolyte membranes for direct methanol fuel cells. Soide State lonics 46: 169-173.

28. Plotarzewski Z, Wieczorek W, Przyluski J, Antonucci V (1999) Novel proton conducting composite electrolytes for application in methanol fuel cells. Solid State lonics 119: 301-304.

29. Miyake N, Wainright JS, Savinell RF (2001) Evaluation of a sol-gel derived Nafion/silica hybrid membrane for proton electrolyte membrane fuel cel applications. J Electrochem Soc 148: A898-A904.

30. Neoh KG, Tan KK, Goh PL, Huang SW, Kang ET, et al. (1999) Electroactive polymer-SiO ${ }_{2}$ nanocomposites for metal uptake.Polymer 40: 887-893.

31. Cho JW, Sul KI (2001) Characterization and properties of hybrid composites prepared from poly(vinylidene fluoride-tetrafluoroethylene) and $\mathrm{SiO}_{2}$. Polymer 42: $727-736$

32. Hegazy EA , El-Assy NB, Dessouki AM and Shaker MM (1989) Radiat Phys Chem 33: 13-18

33. Li Q, He R, Jensen JO, Bjerrum NJ (2003) Approaches and recent developmen of polymer electrolyte membranes for fuel cells operating above $100{ }^{\circ} \mathrm{C}$. Chem Mater 15: 4896-4915.

34. Proceedings of the 'Solid State Protonic Conductors 12' Conference, Uppsala (Sweden); Solid State Ionics; in press.

35. Jung DH, Cho SY, Peck DH, Shin DR, Kim JS (2002) Performance evaluation of a Nafion/silicon oxide hybrid membrane for direct methanol fuel cell. J Power Sour 106: 173-177.

36. Yamaguchi K, Miyata F, Nakao S (2003) Pore-filling type polymer electrolyte membranes for a direct methanol fuel cell .J Membr Sci 214: 283-292.

37. Hegazy EA, Ishigaki I, Dessoui AM, Rabie A, Okamoto J (1982) The study on radiation grafting of acrylic acid onto fluorine containing polymers. III. Kinetic study of preirradiation grafting onto poly (tetrafluoroethylene hexa fluoro propylene). J Appl Polym Sci 27: 535-543.

38. Bae B, Kim D (2003) Sulfonated polystyrene grafted polypropylene composite electrolyte membranes for direct methanol fuel cells. J Membr Sci 220: 75-87.

39. EL-Toony MM (2007) PH.D Thesis of The Use of Ionization Radiation for the Modification of Some Polymeric Materials for Use in Practical Applications. Faculty of Science, El-Menofia University. 
Citation: Abdel-Hady EE, El-Toony MM, Abdel-Hamed MO, Hammam AM (2011) Grafting of Styrene onto Commercial PTFE Membrane and Sulfonation for Possible Use in Fuel Cell. J Membra Sci Technol 1:108. doi:10.4172/2155-9589.1000108

Page 8 of 8

40. Zhi-Li X, Chapiro A, Schmitt N (1993) Grafting of vinylimidazole into air irradiated polymer films-grafting into Teflon-FEP. Radiat Phys Chem 29: 301303
41. Rouilly M, Kotz ER, Haas O, Sherer GG and Chapiro A (1993) Proton exchange membranes prepared by simultaneous radiation grafting of styrene onto TeflonFEP films, synthesis and characterization. J membrane Sci 81: 89-95. 